\title{
Communication \\ Effect of Service-Induced Degradation on Residual Stress Rupture Life of a Directionally Solidified Superalloy
}

\author{
Xiaotong Guo ${ }^{1,2, \dagger}$, Weijie Xing ${ }^{3, \dagger}$, Heng Zhang ${ }^{2}$, Yong $\mathrm{Li}^{1,2}$, Hemeng Peng ${ }^{1,4}$ and Chuan Yang ${ }^{1, *}$ \\ 1 Chongqing CEPREI Industrial Technology Research Institute Co., Ltd., Chongqing 401332, China; \\ guoxiaotong@ceprei.com (X.G.); liyong@ceprei.com (Y.L.); penghemeng@ceprei.com (H.P.) \\ 2 China Electronic Product Reliability and Environmental Testing Research Institute, Guangzhou 511370, China; \\ zhangheng@ceprei.com \\ 3 AECC Beijing Institute of Aeronautical Materials, Beijing 100095, China; xingweijie@biam.com \\ 4 Chongqing Institute of Green and Intelligent Technology, Chinese Academy of Sciences, \\ Chongqing 400714, China \\ * Correspondence: yangchuan@ceprei.com; Tel.: 023-86968006 \\ + These authors contributed equally to this work.
}

Citation: Guo, X.; Xing, W.; Zhang, H.; Li, Y.; Peng, H.; Yang, C. Effect of Service-Induced Degradation on Residual Stress Rupture Life of a Directionally Solidified Superalloy. Crystals 2022, 12, 267. https:// doi.org/10.3390/cryst12020267 Academic Editors: Yanhui Chen, Yunsong Zhao and José, L. Garcia

Received: 25 January 2022

Accepted: 14 February 2022

Published: 16 February 2022

Publisher's Note: MDPI stays neutral with regard to jurisdictional claims in published maps and institutional affiliations.

Copyright: (C) 2022 by the authors. Licensee MDPI, Basel, Switzerland. This article is an open access article distributed under the terms and conditions of the Creative Commons Attribution (CC BY) license (https:// creativecommons.org/licenses/by/ $4.0 /)$.

\begin{abstract}
The influence of service-induced degradation on residual life is very important for the safe service of turbine blades. In this study, a series of simulation experiments were conducted on a directionally solidified superalloy under (880-1020) ${ }^{\circ} \mathrm{C} /(70-220) \mathrm{MPa}$ and interrupted after $500 \mathrm{~h}$. Then, the stress rupture life of the interrupted specimens was tested under $980{ }^{\circ} \mathrm{C} / 275 \mathrm{MPa}$. The results showed that the increase of simulated experiment temperature decreased the residual stress rupture life. In brief, the simulation experiments at $880^{\circ} \mathrm{C}$ did not influence the residual stress rupture life of the alloy. The simulated experiments at $980{ }^{\circ} \mathrm{C}$ and $1050{ }^{\circ} \mathrm{C}$ mainly affected the microstructure of $\gamma^{\prime}$ phase, while not $\gamma / \gamma^{\prime}$ eutectic and carbides. After the stress rupture tests under $980{ }^{\circ} \mathrm{C} / 275 \mathrm{MPa}$, cracks were located at the interfaces between carbides and $\gamma$ matrix in the interdendritic regions. This study provides guidance on the degradation evaluation and safety service of the directionally solidified superalloys.
\end{abstract}

Keywords: directionally solidified superalloy; service induced degradation; stress rupture property; microstructure; $\gamma^{\prime}$ phase

\section{Introduction}

Nickel-based superalloys are widely used to prepare aeroengine turbine blades because of their excellent comprehensive properties [1]. Under normal service conditions, the engines will be overhauled after a period of service, and the blades will undergo a rejuvenation treatment to prolong the service life $[2,3]$. Therefore, after the blade has been in service for some period, the residual service life is very important for users to avoid premature failure, which would result in serious safety accidents and economic losses. At the same time, due to the harsh service environment, the blades will suffer various forms of failure or damage, such as fatigue [4], creep [5,6], corrosion and so on [7]. With the continuous improvement of aeroengine design, manufacturing level and coating technology, the service life of the engine is prolonged. Meanwhile, failure mainly caused by fatigue, oxidation and corrosion will be significantly reduced. Thus, the degradation of creep property caused by microstructure degradation will become the key factor causing engine failure during the service process $[8,9]$.

The microstructure of directionally solidified superalloys usually include $\gamma^{\prime}$ phase, $\gamma / \gamma^{\prime}$ eutectic, different types of carbides and grain boundary. Various forms of microstructural degradation may occur under the coupling of high temperature and stress. For example, the $\gamma^{\prime}$ phase coarsening, rafting and dissolution [10-12], degeneration of MC carbides to $\mathrm{M}_{6} \mathrm{C}$ and $\mathrm{M}_{23} \mathrm{C}_{6}$ [12], $\gamma / \gamma^{\prime}$ eutectic dissolution [13] and even initial melting [14]. 
All the above microstructure evolution could significantly impact the creep properties of the alloys. At the same time, the temperature and stress of the blades are constantly changing during service [15], and further increases the complexity of the effect of service microstructure degradation on the residual stress rupture life. Therefore, to study the effect of service degradation on the residual life of directionally solidified superalloy blades, it is necessary to consider a variety of service temperatures and stresses.

In this study, a widely used directional solidification superalloy was selected as the research object. According to the service environment characteristics of the alloy blade, the service simulation experiments were carried out under the conditions of $(880-1020){ }^{\circ} \mathrm{C} /(70-220) \mathrm{MPa}$, and studied the effect of service degradation on the stress rupture life under the condition of $980{ }^{\circ} \mathrm{C} / 275 \mathrm{MPa}$. Combined with the systematic analysis of microstructure, the effect of service-induced degradation on residual stress rupture life was revealed.

\section{Materials and Methods}

The solidified solid bars were produced by Beijing Institute of Aeronautical Materials, and all bars experienced the standard solution treatment: $1260{ }^{\circ} \mathrm{C} / 1 \mathrm{~h}+1275^{\circ} \mathrm{C} / 1 \mathrm{~h}$ with air cooling $+1120{ }^{\circ} \mathrm{C} / 4 \mathrm{~h}$ with air cooling $+1080{ }^{\circ} \mathrm{C} / 4 \mathrm{~h}$ with air cooling $+870{ }^{\circ} \mathrm{C} / 16 \mathrm{~h}$ with air cooling. The chemical composition of the alloy was (in wt.\%) 11.98 Co-6.77 Cr-6.28 Ta-6.02 Al-4.84 W-2.92 Re-1.53 Mo-1.48 Hf-0.12 C with a balance of Ni. The conditions of simulated service experiments are listed in Table 1 , and were interrupted after $500 \mathrm{~h}$ except for the simulation experiment under $1020^{\circ} \mathrm{C} / 150 \mathrm{MPa}$, because the sample broke after about $300 \mathrm{~h}$. After the simulated experiments, specimens were subjected to stress rupture tests under $980{ }^{\circ} \mathrm{C} / 275 \mathrm{MPa}$ to measure the residual stress rupture life. The sketch of the stress rupture specimens is shown in reference [12], and the diameter and length of the gauge area was $5 \mathrm{~mm}$ and $25 \mathrm{~mm}$, respectively. Four specimens were measured for one statistical result. Samples were sectioned, ground, polished, and subjected to selective etching to observe the microstructure morphologies. To observe the morphologies of the cracks and carbides, samples were chemically etched in a solution containing $4 \mathrm{~g}$ copper sulfate, $20 \mathrm{ml}$ hydrochloric acid, $16 \mathrm{ml}$ water and $1 \mathrm{ml}$ sulfuric acid. To observe the morphology of the $\gamma^{\prime}$ precipitates, samples were electrochemically etched, and the solution contained $3 \mathrm{ml}$ phosphoric, $12 \mathrm{ml}$ sulfuric acid and $10 \mathrm{ml}$ nitric. A NIKON LV150 optical microscope, and an FEI Inspect F50 field-emission scanning electron microscope (FE-SEM) were used to observe the microstructures.

Table 1. The temperature and stress under the simulated service conditions.

\begin{tabular}{ccc}
\hline Temperature $/{ }^{\circ} \mathbf{C}$ & Stress/MPa & Duration $/ \mathbf{h}$ \\
\hline \multirow{3}{*}{1020} & 150 & \\
& 100 & \\
\multirow{2}{*}{980} & 70 & 500 \\
& 180 & \\
\hline \multirow{2}{*}{880} & 110 & \\
& 70 & \\
\hline
\end{tabular}

\section{Results and Discussion}

\subsection{Stress Rupture Properties}

The measured stress rupture life of the alloy at $980{ }^{\circ} \mathrm{C} / 275 \mathrm{MPa}$ after the standard heat treatment was $50 \mathrm{~h}$ [16]. According to the simulated experimental conditions (Table 1), the stress rupture tests were conducted under (880-1020) ${ }^{\circ} \mathrm{C} /(70-220) \mathrm{MPa}$ and interrupted after $500 \mathrm{~h}$, following by furnace cooling. The samples broke after the experiment had been carried out for about $300 \mathrm{~h}$ under $1020^{\circ} \mathrm{C} / 150 \mathrm{MPa}$. For the interrupted samples under 
other conditions, the stress rupture tests under $980^{\circ} \mathrm{C} / 275 \mathrm{MPa}$ were subsequently carried out, and the results are shown in Figure 1.

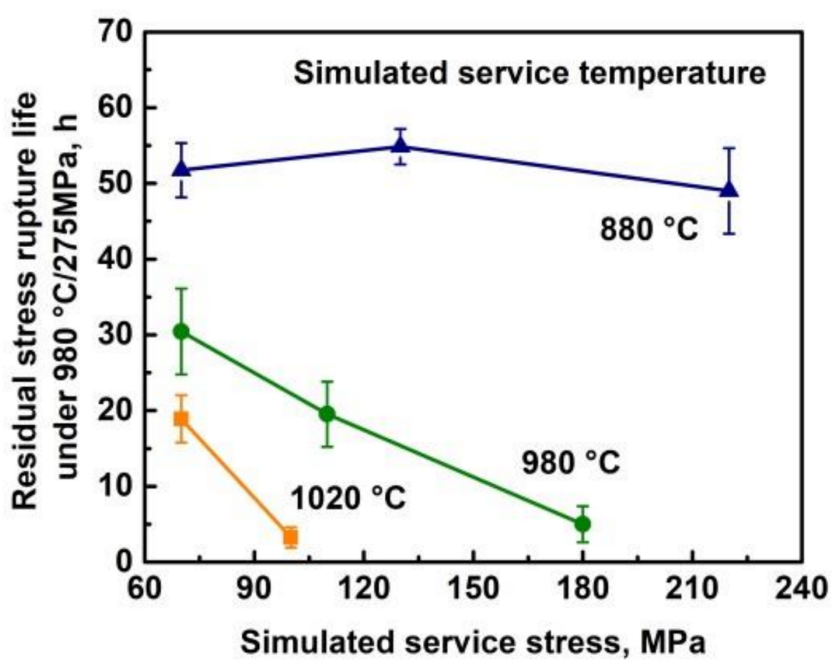

Figure 1. Residual stress rupture life under $980^{\circ} \mathrm{C} / 275 \mathrm{MPa}$ under the different simulated service environmental conditions, the blue, green and yellow lines correspond to simulated service temperature of $880{ }^{\circ} \mathrm{C}, 980^{\circ} \mathrm{C}$ and $1020^{\circ} \mathrm{C}$, respectively.

The simulation experiments may lead to the obvious decrease of the stress rupture life of the alloy under $980^{\circ} \mathrm{C} / 275 \mathrm{MPa}$. After experiencing the simulation experiments at $880^{\circ} \mathrm{C}$ for $500 \mathrm{~h}$, the average residual stress rupture life was maintained for about $50 \mathrm{~h}$, indicating that the influence on the stress rupture property is relatively small. With the increase of the simulated service temperature, the residual stress rupture life decreased rapidly. For example, after the simulation experiment at $1020^{\circ} \mathrm{C} / 100 \mathrm{MPa}$ for $500 \mathrm{~h}$, the stress rupture life at $980^{\circ} \mathrm{C} / 275 \mathrm{MPa}$ was only $3.3 \mathrm{~h}$. The applied stress also had a significant effect on the residual stress rupture life of the alloy. At the simulated experimental temperature $980{ }^{\circ} \mathrm{C}$, the residual stress rupture life decreased from $30.4 \mathrm{~h}$ to $5.0 \mathrm{~h}$ when the applied stress increased from $70 \mathrm{MPa}$ to $180 \mathrm{MPa}$.

\subsection{Microstructural Degradation after the Simulated Service Process}

In order to clarify the effect of service degradation on the residual stress rupture life of the alloy, the microstructures under simulated service conditions were systematically characterized and analyzed. After the simulated experiments, the morphologies of the $\gamma / \gamma^{\prime}$ eutectics and carbides were close to those of the alloy after the standard solution treatment $[12,13]$. The $\gamma / \gamma^{\prime}$ eutectic maintained a sunflower shape, and the granular carbides dispersed in the interdendritic regions and grain boundaries, as shown in Figure 2a,b.

The simulated experiments had a significant effect on the microstructural degradation of $\gamma^{\prime}$ phase, and the morphologies of the $\gamma^{\prime}$ precipitates in the longitudinal sections were systematically characterized, as shown in Figure $2 \mathrm{c}-\mathrm{k}$. At $1020^{\circ} \mathrm{C}$, the $\gamma^{\prime}$ phase coarsened and rafted. The coarsening and rafting of the $\gamma^{\prime}$ phase were the most serious at $150 \mathrm{MPa}$, and the raft structure showed a "wave" shape. With the decrease of stress, the "wave" degree of the raft structure decreased, and the raft structure was basically straight at $70 \mathrm{MPa}$. At $980{ }^{\circ} \mathrm{C}$, the coarsening and rafting of the $\gamma^{\prime}$ phase was obvious, and also showed a "wave" shape at $110 \mathrm{MPa}$. With the decrease of stress, the "wave" shape of the rafe structure decreased. The raft structure was basically straight at $70 \mathrm{MPa}$, which was more regular than that at $1020{ }^{\circ} \mathrm{C} / 70 \mathrm{MPa}$, as shown in Figure $2 \mathrm{f}-\mathrm{h}$. At $880^{\circ} \mathrm{C}$, the microstructure change of $\gamma^{\prime}$ phase was small and only slightly rafted at $220 \mathrm{MPa}$, while it could be ignored at $130 \mathrm{MPa}$ and $70 \mathrm{MPa}$ (Figure 2i-k). 


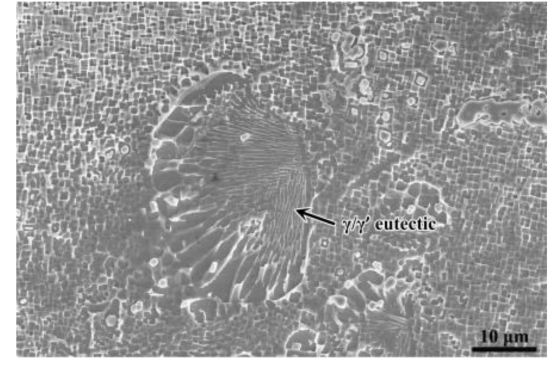

(a)

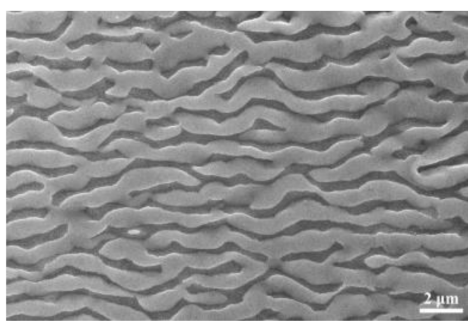

(c)

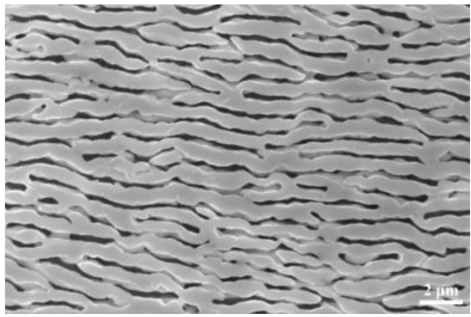

(f)

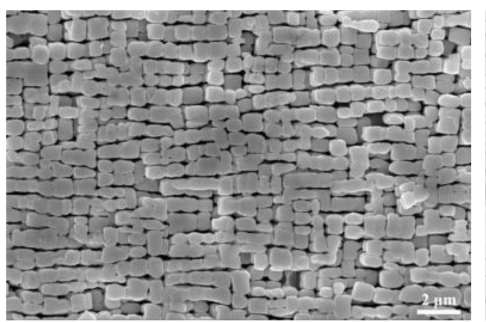

(i)

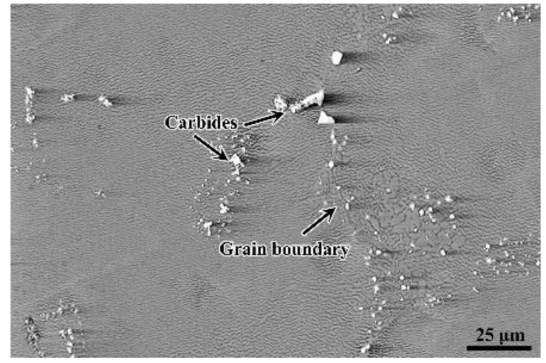

(b)

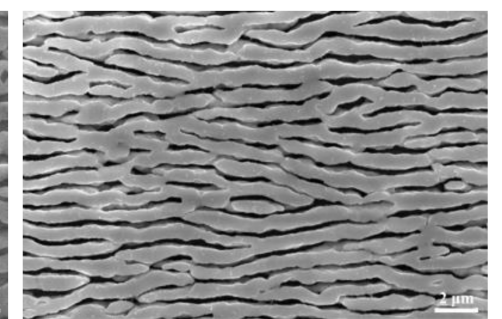

(d)

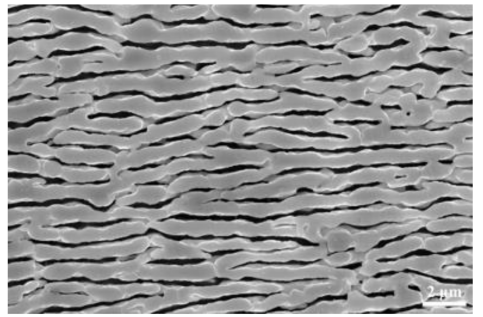

(g)

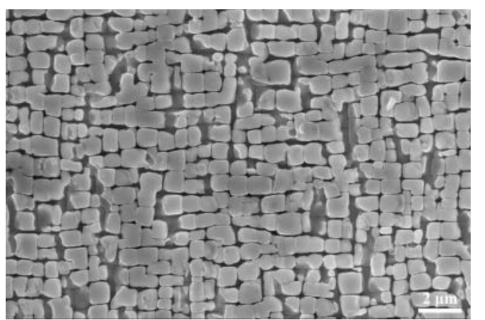

(j)

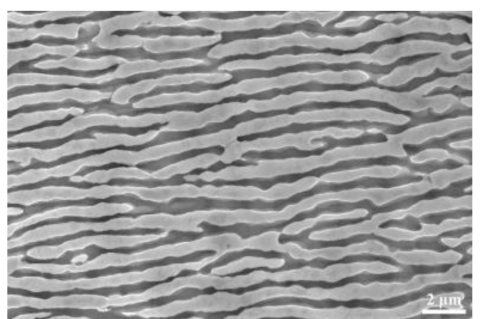

(e)

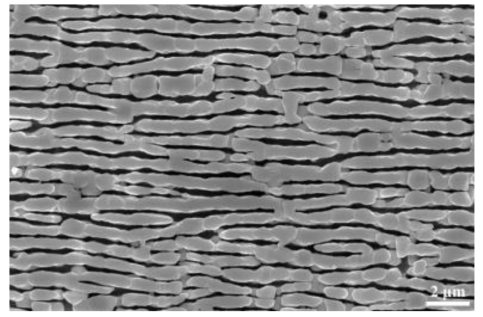

(h)

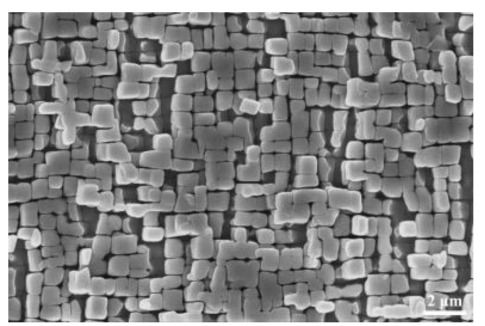

(k)

Figure 2. Microstructure morphologies after different simulated experiments: scanning electron microscopy back-scattered electron (SEM-BSE) images of the $\gamma / \gamma^{\prime}$ eutectic (a) and carbides in the interdendritic regions (b) under $1020^{\circ} \mathrm{C} / 150 \mathrm{MPa}$; SEM-SE images of the $\gamma^{\prime}$ precipitates in the dendrite cores along longitudinal sections under $1020^{\circ} \mathrm{C} / 150 \mathrm{MPa}$ (c), $1020^{\circ} \mathrm{C} / 100 \mathrm{MPa}$ (d), $1020{ }^{\circ} \mathrm{C} / 70 \mathrm{MPa}$ (e), $980{ }^{\circ} \mathrm{C} / 180 \mathrm{MPa}(\mathbf{f}), 980{ }^{\circ} \mathrm{C} / 110 \mathrm{MPa}(\mathbf{g}), 980^{\circ} \mathrm{C} / 70 \mathrm{MPa}(\mathbf{h}), 880^{\circ} \mathrm{C} / 220 \mathrm{MPa}(\mathbf{i}), 880^{\circ} \mathrm{C} / 130 \mathrm{MPa}$ (j), $880^{\circ} \mathrm{C} / 70 \mathrm{MPa}(\mathbf{k})$.

Overall, the $\gamma^{\prime}$ phase presented rafting in different degrees at $1020^{\circ} \mathrm{C}$ and $980{ }^{\circ} \mathrm{C}$, and the "wave" degree of rafting increased with the increase of stress. The $\gamma^{\prime}$ phase was hardly rafted after the simulated experiments at $880^{\circ} \mathrm{C}$ for $500 \mathrm{~h}$, and the morphology of $\gamma^{\prime}$ phase was close to that after the standard heat treatment [12]. The microstructure characteristics showed that under the simulated experiments of (980-1020) ${ }^{\circ} \mathrm{C} /(70-130) \mathrm{MPa}$, rafting of the $\gamma^{\prime}$ phase occurred in varying degrees and led to the reduction of the residual life in the subsequent continuous service. Under the simulated experiments of $880^{\circ} \mathrm{C} /(70-200) \mathrm{MPa}$, there was no obvious microstructure degradation of the carbides and $\gamma^{\prime}$ precipitates, and this had little influence on the stress ruputre life under $980{ }^{\circ} \mathrm{C} / 275 \mathrm{MPa}$. 


\subsection{Microstructure Morphologies after the Stress Rupture Tests}

For the investigated alloy, cracks always occurred in the interdendritic regions during stress rupture tests under $980^{\circ} \mathrm{C} / 275 \mathrm{MPa}$. The results of this study are consistent with the previous conclusions [12,13], and because the carbide morphology in the alloy was close and unchanged under different simulated service conditions, the fracture morphology was consistent after $980^{\circ} \mathrm{C} / 275 \mathrm{MPa}$ stress rupture tests [12]. Plastic deformation occurred in all the stress rupture fracture specimens, and numerous dimples were distributed on the macro fracture, with carbides in the middle of the dimples. The crack characteristics of the longitudinal section of the fracture verify the macro fracture characteristics. Figure 3 shows the SEM-BSE images of the stress rupture voids along the longitudinal sections in the specimens under $980^{\circ} \mathrm{C} / 70 \mathrm{MPa}$ after being exposed to $1020^{\circ} \mathrm{C} / 70 \mathrm{MPa}$ for $500 \mathrm{~h}$. Creep voids distributed in the interdendritic regions (Figure $3 \mathrm{a}$ ), and located at the interfaces of MC carbides and $\gamma$ matrix. For polycrystalline cast superalloys containing carbides, such as equiaxed superalloys $[17,18]$ and directionally solidified superalloys [10], the difference of thermal expansion coefficient between carbides and matrix easily leads to stress concentration at the interface. Under the coupling action of high temperature and stress, cracks easily initiate and progress at the interface, resulting in alloy cracking. In this study, the carbides did not undergo microstructural degradation in the simulated service process, and the lasting fracture modes of different simulated service samples were basically the same under $980^{\circ} \mathrm{C} / 275 \mathrm{MPa}$.

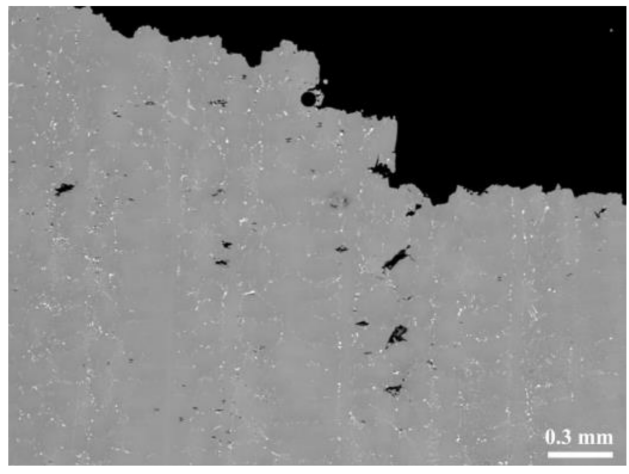

(a)

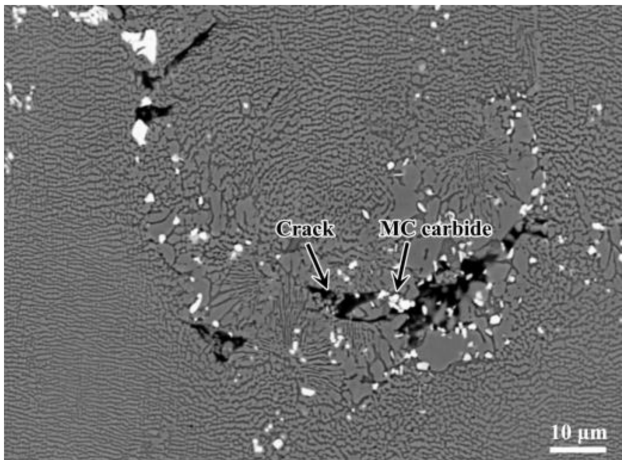

(b)

Figure 3. SEM-BSE images of the stress rupture voids at a lower magnification (a) and a higher magnification (b) along the longitudinal sections in the specimens under $980{ }^{\circ} \mathrm{C} / 70 \mathrm{MPa}$ after being exposed to $1020^{\circ} \mathrm{C} / 70 \mathrm{MPa}$ for $500 \mathrm{~h}$.

The above results indicate that $\gamma^{\prime}$ phase rafting has a significant effect on the stress rupture property of the alloy, and the microstructures of the $\gamma^{\prime}$ precipitates are thus characterized to ascertain the rafting law in the fracture specimens under $980^{\circ} \mathrm{C} / 275 \mathrm{MPa}$. For specimens under the simulated service conditions at $1020^{\circ} \mathrm{C}$ and $980^{\circ} \mathrm{C}$, the $\gamma^{\prime}$ phase had been rafted after the simulated experiments, so the subsequent $980^{\circ} \mathrm{C} / 275 \mathrm{MPa}$ experimental process would only increase the rafting degree to some extent. During the simulated experiments at $880^{\circ} \mathrm{C}$ for up to $500 \mathrm{~h}$, the $\gamma^{\prime}$ phase remained cuboidal (Figure 2i-k), which was mainly due to the relatively low service temperature in comparison with the microstructural stability of the $\gamma^{\prime}$ phase [12]. During the stress rupture tests under $980^{\circ} \mathrm{C} / 275 \mathrm{MPa}$, the $\gamma^{\prime}$ precipitates also suffered rafting even after $50 \mathrm{~h}$ following the simulated service under $880^{\circ} \mathrm{C} / 70 \mathrm{MPa}$ (Figure 4). This phenomenon means that there is a critical temperature for the rafting of the $\gamma^{\prime}$ phase, and the critical value is between $880^{\circ} \mathrm{C}$ and $980^{\circ} \mathrm{C}$. Obviously, below the critical temperature, the microstructure of the alloy does not degrade and the service degradation can be ignored. However, above the critical temperature, especially under the condition of large stress, the service degradation easily leads to obvious degradation of stress rupture properties. Besides, the sensitivity of $\gamma^{\prime}$ phase microstructure evolution to service temperature can be used to evaluate blade service degradation. For example, 
the degree of $\gamma^{\prime}$ rafting and the area fraction of the $\gamma^{\prime}$ phase are used to inversely evaluate the service temperature and stress of the turbine blades [11,19]. For the alloy in this study, more work needs to be done to evaluate the service degradation of blades.

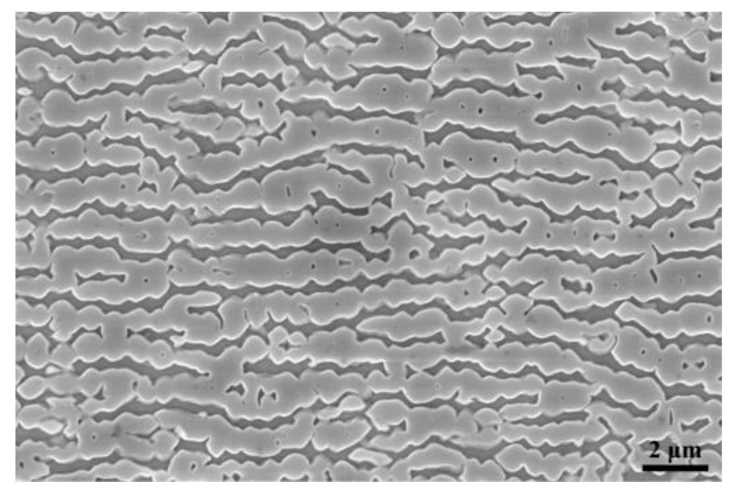

Figure 4. SEM-SE images of the $\gamma^{\prime}$ precipitates in the dendrite cores away from the fracture along the longitudinal sections for the specimens under $980^{\circ} \mathrm{C} / 275 \mathrm{MPa}$ after being exposed to $880{ }^{\circ} \mathrm{C} / 70 \mathrm{MPa}$ for $500 \mathrm{~h}$.

Overall, for directionally solidified superalloys, the strengthening mechanism of the $\gamma^{\prime}$ phase has the most significant effect on the stress rupture property. The grain boundary and carbides always act as weak regions, which often become areas of crack initiation and propagation. In this study, the microstructure degradation in the alloy was mainly manifested in $\gamma^{\prime}$ rafting after being exposed to $980^{\circ} \mathrm{C}$ and $1020^{\circ} \mathrm{C}$ for up to $500 \mathrm{~h}$. The applied stress will increase the rafting of $\gamma^{\prime}$ phase and reduce the subsequent stress rupture property, and even result in premature fracture before $500 \mathrm{~h}$.

\section{Conclusions}

In this study, experiments were carried out on a widely used directionally solidified superalloy under the conditions of $(880-1020){ }^{\circ} \mathrm{C} /(70-220) \mathrm{MPa}$ to simulate the service process under different conditions. The stress rupture tests were then conducted on the interrupted samples under $980{ }^{\circ} \mathrm{C} / 275 \mathrm{MPa}$, combined with the systematic characterization of macro-fracture mode, microstructures including $\gamma / \gamma^{\prime}$ eutectic, carbides and $\gamma^{\prime}$ precipitates. The effect of service degradation on the residual stress rupture life of the alloy was determined. Several conclusions are summarized as follows:

(1) The simulated experiment temperature had the greatest influence on the residual stress rupture life under $980^{\circ} \mathrm{C} / 275 \mathrm{MPa}$. With the increase of simulated experimental temperature, the residual stress rupture life decreased rapidly. At simulated experimental temperature of $880{ }^{\circ} \mathrm{C}$, the residual stress rupture life was maintained at about $45 \mathrm{~h}$ regardless of the serviced stress.

(2) After the simulated experiments of $500 \mathrm{~h}$, the morphologies of $\gamma / \gamma^{\prime}$ eutectic and carbides were unchanged, while $\gamma^{\prime}$ rafting occurred to varying degrees. In the subsequent $980{ }^{\circ} \mathrm{C} / 275 \mathrm{MPa}$ stress rupture tests, the cracks were located at the interfaces between carbides and $\gamma$ matrix in the interdendritic regions.

(3) After being exposed to the simulated experiments under $880{ }^{\circ} \mathrm{C} /(70-220) \mathrm{MPa}$ for $500 \mathrm{~h}$, the $\gamma^{\prime}$ phase remained of cuboidal morphology, while it was rafted after $50 \mathrm{~h}$ under the $980^{\circ} \mathrm{C} / 275 \mathrm{MPa}$ stress rupture test. The investigated alloy had a critical rafting temperature, which was between $880^{\circ} \mathrm{C}$ and $980^{\circ} \mathrm{C}$. Above the critical temperature, service degradation may significantly reduce the residual stress rupture life.

Author Contributions: Experiment conduction-W.X.; data and image processing-X.G., H.Z. and Y.L.; writing—original draft preparation, X.G.; writing—-review and editing, H.P. and C.Y. All authors have read and agreed to the published version of the manuscript. 
Funding: This research was funded by the Science and Technology Program of Guangzhou of China (Grant No. 202102020474), and CEPREI Innovation and Development Foundation (Grant No. $20 Z 33$ and 20Z32).

Institutional Review Board Statement: Not applicable.

Informed Consent Statement: Not applicable.

Data Availability Statement: Not applicable.

Conflicts of Interest: The authors declare that the research was conducted in the absence of any commercial or finical relationships that could be construed as a potential conflict of interest.

\section{References}

1. Pollock, T.M.; Tin, S. Nickel-based superalloys for advanced turbine engines: Chemistry, microstructure and properties. J. Propuls. Power 2006, 22, 361-374. [CrossRef]

2. Báachnio, J.; Pawlak, W. Damageability of gas turbine blades-evaluation of exhaust gas temperature in front of the turbine using a non-linear observer. In Advances in Gas Turbine Technology; InTech: London, UK, 2011; pp. 435-464.

3. Donachie, M.J.; Donachie, S.J. Superalloys: A technical Guide; ASM International: Almere, The Netherlands, 2002.

4. Troshchenko, V.; Prokopenko, A. Fatigue strength of gas turbine compressor blades. Eng. Fail. Anal. 2000, 7, 209-220. [CrossRef]

5. Kargarnejad, S.; Djavanroodi, F. Failure assessment of Nimonic 80A gas turbine blade. Eng. Fail. Anal. 2012, 26, 211-219. [CrossRef]

6. Kim, S.G.; Hwang, Y.-H.; Kim, T.-G.; Shu, C.-M. Failure analysis of J85 Engine turbine blades. Eng. Fail. Anal. 2008, 15, 394-400. [CrossRef]

7. Carter, T.J. Common failures in gas turbine blades. Eng. Fail. Anal. 2005, 12, 237-247. [CrossRef]

8. Zhao, W.X.; Li, Y.; Fan, Y.W.; Zheng, Y.R. Fracture Analysis for Second Stage Rotor Turbine Blade in Aero-engine. J. Mater. Eng. 2012, 8, 39-44.

9. Feng, Q.; Tong, J. Service Damage and Repair of Gas Turbine Blades. Materials 2012, 31, 21-34.

10. An, W.; Utada, S. Thermal cycling creep properties of a directionally solidified superalloy DZ125. J. Mater. Sci. Technol. 2022, 104, 269-284. [CrossRef]

11. Chen, Y.; Zheng, Y.; Feng, Q. Evaluating service temperature field of high pressure turbine blades made of directionally solidified DZ125 superalloy based on micro-structural evolution. Acta. Metall. Sin. 2016, 52, 1545-1556.

12. Xing, W.; Zhu, G. Abnormal creep property degradation in a directionally solidified superalloy DZ406 after suffering overheating. Mater. Charact. 2021, 173, 110910. [CrossRef]

13. Xing, W.; Liu, C. Effect of solution heat treatment on microstructures and stress rupture properties of DZ406 alloy. In Proceedings of the MEACM 2020, Beijing, China, 24-25 October 2020; Springer: Berlin/Heidelberg, Germany, 2021; pp. 421-433.

14. An, W.; Zheng, W. Effect of Short-time Overtemperature on Microstructure and Tensile Properties of Directionally Solidified DZ125 Alloy. Rare Met. 2020, 44, 1009-1018.

15. Cormier, J. Cycling Creep Resistance of Ni-Based Single Crystal Superalloys. In Superalloys 2016: Proceedings of the 13th Intenational Symposium of Superalloys, Seven Springs, PA, USA, 11-15 September 2016; Wiley: Hoboken, NJ, USA, 2016; pp. 385-394.

16. Academic Committee of the Superalloys CSM. China Superalloys Handbook; Standard Press of China: Beijing, China, 2012; pp. 232-255.

17. Guo, X.; Zheng, W. High temperature creep behavior of a cast polycrystalline nickel-based superalloy K465 under thermal cycling conditions. Materialia 2020, 12, 100913. [CrossRef]

18. Yuan, X.F.; Wu, J.T. Effects of initial microstructures on the microstructural evolution and corresponding mechanical property of K424 superalloy after overheating exposure. Mater. Sci. Eng. A 2019, 743, 40-56. [CrossRef]

19. Guo, X.; Zheng, W. Evaluation of microstructural degradation in a failed gas turbine blade due to overheating. Eng. Fail. Anal. 2019, 108, 308-317. [CrossRef] 